\title{
Online Portal for Job Aspirants
}

\author{
K.Shanmugapriya, C.Geetha, B.Sundaraj, S.R.Srividhya
}

\begin{abstract}
Our Application is used to find the jobs present in our nearby places and also the jobs which are available to work in our feasible timings and suitable to our skills. The registered persons will apply for the jobs. After that the organization will check their details and they will contact as they suited for the job willing to do, places where he will be available to work, timings in which he is feasible to work. We also provide registrations for the organizations which are willing to offer jobs. When the organization registers into the website local manager validates whether the organization is real or not. If it is real organization, the local manager permits the access to the organization. The organization is able to post the jobs. If it is not real organization the local manager rejects the organization. Even though they are not interested to register, they can post the job or work details by mentioning the type of work, duration of work, money paid and the number of persons required to do the work. We provide a platform for the persons who offer work to interact with the people who are willing to work.[1] Whenever a requirement for job is posted we will send an automatic notification to the persons who are registered to work. Otherwise the person who offers job can select the person to work based on his qualification and details he provided during registration. They can modify their data in the website by sending a request to the admin. Admin need to approve the request and he will modify the data in the website.
\end{abstract}

Keywords : Manager Projects, Online Portal, Register

\section{INTRODUCTION}

It is a platform that joins organizations and the job seekers to complete their goals and requirements. Recruiters look for a right candidate who has the right qualification to handle the responsibilities efficiently. On the other hand, job seekers want a job where they can apply their skills and knowledge to grow their professional career.[16-20]

\section{SCOPE OF THE SYSTEM}

By using our application user no need to search in the internet. They will be notified automatically about the jobs available. This will reduce the burden of the persons who are searching a job. We provide an interface between the Organisations and the users.[10-15]

Revised Manuscript Received on July 22, 2019.

K.Shanmugapriya Department of Computer Science and Engineering, Bharath Institute of Higher Education and Research, Chennai. Email: shanmugapriyabiher@gmail.com

C.Geetha, Department of Computer Science and Engineering, Bharath Institute of Higher Education and Research, Chennai. Email: gitakannan.2010@gmail.com

B.Sundaraj, Department of Computer Science and Engineering, Bharath Institute of Higher Education and Research, Chennai. Email: sundarrajboobalan@gmail.com

S.R.Srividhya, Department of Computer Science and Engineering, Bharath Institute of Higher Education and Research, Chennai. Email: vidhyasrinivasan1890@gmail.com

\section{EXISITING SYSTEM}

At present, if anyone wants to do jobs they will get the information through newspapers or pamphlets or by any human means of communication. We cannot easily find the job opportunities to work in our convenient timings. It even takes more time to reach every individual about these opportunities.[21-15]

\section{IV.PROPOSED SYSTEM}

People who are searching for jobs will register in our website by providing information like type of jobs he is

\section{A. Usability}

The system should be available over the internet so that the users like adminstrator, user canuse the system from their respective locations.

\section{B. Reliability}

For gaining entry into the system the users should install this application. The system be available 24 X 7 Performance he admin should take care of security.

\section{Supportability}

The system should display a menu for users to choose from. The system should display user's requests in a reasonable time. Flexible service based architecture will be highly desirable for future extension.[25-30]

\section{Physical Environment}

It is only the internet application. Because of this any user can enter into thism application.

\section{F. Resource Requirements}

The requirements that must be specified are every user must have Android mobile with Internet connection.

\section{RESULTS AND DISCUSSION}

A system architecture or systems architecture is the conceptual model that defines the structure, behavior, and more views of a system. An architecture description is a formal description and representation of a system, organized in a way that supports reasoning about the structures and behaviors of the system. A 3-tier architecture is a type of software architecture which is composed of three "tiers" or "layers" of logical computing. They are often used in applications as a specific type of client- server system. 3-tier architectures provide many benefits for production and development environments by modularizing the user interface, business logic, and data storage layers. The three logical tiers are[31-40]

- Presentation tier- 
Android XML

- Middle tier-PHP, Android

- Data tier-MySQL

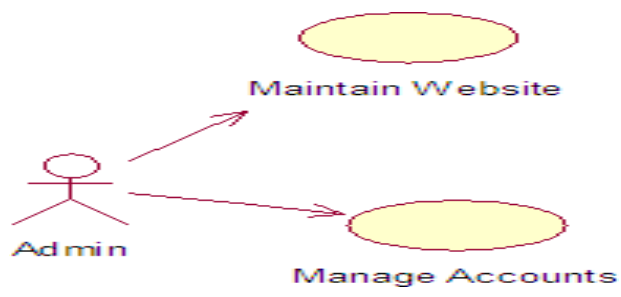

\section{A. Modules}

- Job seeker: Register in the website and applies for required jobs.

- Organization: Register in the website and advertise the job posts.[5]

- Manager: Cheeks whether the organization is real or not, and approves the organization.[41]

- Admin: Stores and maintains the whole

\section{B. Data Base}

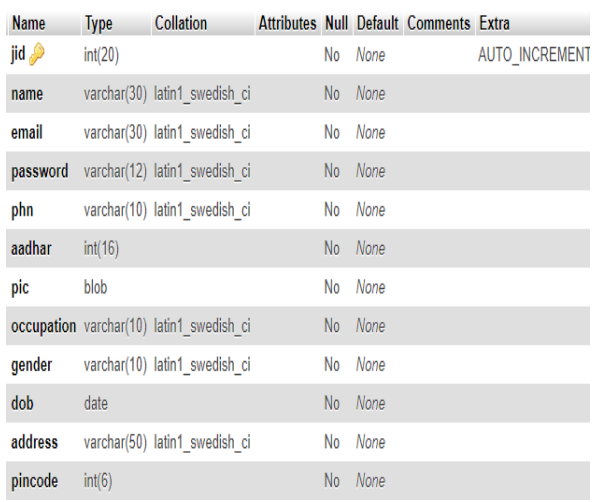

\section{CONCLUSION}

It provides an easy access for the people to find their jobs in their suitable locations, timings and with their skills and also they can check all other jobs. It also helps the organizations or an individual by providing platform where they can easily hire people for jobs and check the applied candidates and contact them as they are suitable to the job. As it will have a local manager for every major locality and he will accept the organization request at the time of organization registration. [6]People who are searching for jobs will register in our website by providing information like type of jobs he is willing to do, places where he will be available to work, timings in which he is feasible to work. We also provide registrations for the organizations which are willing to offer jobs. When the organization registers into the

website local manager validates whether the organization is real or not. If it is real organization, the local manager permits the access to the organization. The organization is able to post the jobs.[7] If it is not real organization the local manager rejects the organization. Even though they are not interested to register, they can post the job or work details by mentioning the type of work, duration of work, money paid and the number of persons required to do the work. We provide a platform for the persons who offer work to interact with the people who are willing to work. Whenever a requirement for job is posted we will send an automatic notification [8] to the persons who are registered to work. Otherwise the person who offers job can select the person to work based on his qualification and details he provided during registration. They can modify their data in the website by sending a request to the admin. Admin need to approve the request and he will modify the data in the website.[9]

\section{REFERENCES}

[1] Kumaravel A., Rangarajan K.,Algorithm for automaton specification for exploring dynamic labyrinths,Indian Journal of Science and Technology,V-6,I-SUPPL5,PP-4554-4559,Y-2013

[2] P. Kavitha, S. Prabakaran "A Novel Hybrid Segmentation Method with Particle Swarm Optimization and Fuzzy C-Mean Based On Partitioning the Image for Detecting Lung Cancer" International Journal of Engineering and Advanced Technology (IJEAT) ISSN: 2249-8958, Volume-8 Issue-5, June 2019

[3] Kumaravel A., Meetei O.N.,An application of non-uniform cellular automata for efficient cryptography,2013 IEEE Conference on Information and Communication Technologies, ICT 2013,V-,I-,PP-1200-1205,Y-2013

[4] Kumarave A., Rangarajan K.,Routing alogrithm over semi-regular tessellations,2013 IEEE Conference on Information and Communication Technologies, ICT 2013,V-,I-,PP-1180-1184,Y-2013

[5] P. Kavitha, S. Prabakaran "Designing a Feature Vector for Statistical Texture Analysis of Brain Tumor" International Journal of Engineering and Advanced Technology (IJEAT) ISSN: 2249-8958, Volume-8 Issue-5, June 2019

[6] Dutta P., Kumaravel A.,A novel approach to trust based identification of leaders in social networks,Indian Journal of Science and Technology,V-9,I-10,PP--,Y-2016

[7] Kumaravel A., Dutta P.,Application of Pca for context selection for collaborative filtering,Middle - East Journal of Scientific Research,V-20,I-1,PP-88-93,Y-2014

[8] Kumaravel A., Rangarajan K.,Constructing an automaton for exploring dynamic labyrinths,2012 International Conference on Radar, Communication and Computing, ICRCC 2012,V-,I-,PP-161-165,Y-2012

[9] P. Kavitha, S. Prabakaran "Adaptive Bilateral Filter for Multi-Resolution in Brain Tumor Recognition" International Journal of Innovative Technology and Exploring Engineering (IJITEE) ISSN: 2278-3075, Volume-8 Issue-8 June, 2019

[10] Kumaravel A.,Comparison of two multi-classification approaches for detecting network attacks, World Applied Sciences Journal,V-27,I-11,PP-1461-1465,Y-2013

[11] Tariq J., Kumaravel A.,Construction of cellular automata over hexagonal and triangular tessellations for path planning of multi-robots,2016 IEEE International Conference on Computational Intelligence and Computing Research, ICCIC 2016,V-,I-,PP--,Y-2017

[12] Sudha M., Kumaravel A.,Analysis and measurement of wave guides using poisson method,Indonesian Journal of Electrical Engineering and Computer Science,V-8,I-2,PP-546-548,Y-2017

[13] Ayyappan G., Nalini C., Kumaravel A.,Various approaches of knowledge transfer in academic social network,International Journal of Engineering and Technology,V-,I-,PP-2791-2794,Y-2017

[14] Kaliyamurthie, K.P., Sivaraman, K., Ramesh, S. Imposing patient data privacy in wireless medical sensor networks through homomorphic 
cryptosystems 2016, Journal of Chemical and Pharmaceutical Sciences92.

[15] Kaliyamurthie, K.P., Balasubramanian, P.C. An approach to multi secure to historical malformed documents using integer ripple transfiguration 2016 Journal of Chemical and Pharmaceutical Sciences92.

[16] A.Sangeetha,C.Nalini,"Semantic Ranking based on keywords extractions in the web", International Journal of Engineering \& Technology, 7 (2.6) (2018) 290-292

[17] S.V.GayathiriDevi,C.Nalini,N.Kumar,"An efficient software verification using multi-layered software verification tool "International Journal of Engineering \& Technology, 7(2.21)2018 454-457

[18] C.Nalini,ShwtambariKharabe,"A Comparative Study On Different Techniques Used For Finger - Vein Authentication", International Journal Of Pure And Applied Mathematics, Volume 116 No. 82017 , 327-333, Issn: 1314-3395

[19] M.S. Vivekanandan and Dr. C. Rajabhushanam, "Enabling Privacy Protection and Content Assurance in Geo-Social Networks", International Journal of Innovative Research in Management, Engineering and Technology, Vol 3, Issue 4, pp. 49-55, April 2018

[20] Dr. C. Rajabhushanam, V. Karthik, and G. Vivek, "Elasticity in Cloud Computing", International Journal of Innovative Research in Management, Engineering and Technology, Vol 3, Issue 4, pp. 104-111, April 2018.

[21] K. Rangaswamy and Dr. C. Rajabhushanamc, "CCN-Based Congestion Control Mechanism In Dynamic Networks", International Journal of Innovative Research in Management, Engineering and Technology, Vol 3, Issue 4, pp. 117-119, April 2018.

[22] Kavitha, R., Nedunchelian, R., "Domain-specific Search engine optimization using healthcare ontology and a neural network backpropagation approach", 2017, Research Journal of Biotechnology, Special Issue 2:157-166

[23] Kavitha, G., Kavitha, R., "An analysis to improve throughput of high-power hubs in mobile ad hoc network", 2016, Journal of Chemical and Pharmaceutical Sciences, Vol-9, Issue-2: 361-363

[24] Kavitha, G., Kavitha, R., "Dipping interference to supplemen throughput in MANET", 2016, Journal of Chemical and Pharmaceutical Sciences, Vol-9, Issue-2: 357-360

[25] Michael, G., Chandrasekar, A.,'Leader election based malicious detection and response system in MANET using mechanism design approach", Journal of Chemical and Pharmaceutical Sciences(JCPS) Volume 9 Issue 2, April - June 2016

[26] Michael, G., Chandrasekar, A.,'Modeling of detection of camouflaging worm using epidemic dynamic model and power spectral density", Journal of Chemical and Pharmaceutical Sciences(JCPS) Volume 9 Issue 2, April - June 2016.

[27] Pothumani, S., Sriram, M., Sridhar, J., Arul Selvan, G., Secure mobile agents communication on intranet,Journal of Chemical and Pharmaceutical Sciences, volume 9, Issue 3, Pg No S32-S35, 2016

[28] Pothumani, S., Sriram, M., Sridhar , Various schemes for database encryption-a survey, Journal of Chemical and Pharmaceutical Sciences, volume 9, Issue 3, Pg NoS103-S106, 2016

[29] Pothumani, S., Sriram, M., Sridhar, A novel economic framework for cloud and grid computing, Journal of Chemical and Pharmaceutical Sciences, volume 9, Issue 3, Pg No S29-S31, 2016

[30] Priya, N., Sridhar, J., Sriram, M. "Ecommerce Transaction Security Challenges and Prevention Methods- New Approach” 2016 ,Journal of Chemical and Pharmaceutical Sciences, JCPS Volume 9 Issue 3.page no:S66-S68 .

[31] Priya, N.,Sridhar,J.,Sriram, M."Vehicular cloud computing security issues and solutions" Journal of Chemical and Pharmaceutical Sciences(JCPS) Volume 9 Issue 2, April - June 2016

[32] Priya, N., Sridhar, J., Sriram, M. "Mobile large data storage security in cloud computing environment-a new approach" JCPS Volume 9 Issue 2. April - June 2016

[33] Anuradha.C, Khanna.V, "Improving network performance and security in WSN using decentralized hypothesis testing "Journal of Chemical and Pharmaceutical Sciences(JCPS) Volume 9 Issue 2, April - June 2016.

[34] Anuradha.C, Khanna.V, "A novel gsm based control for e-devices" Journal of Chemical and Pharmaceutical Sciences(JCPS) Volume 9 Issue 2, April - June 2016

[35] Anuradha.C, Khanna.V, "Secured privacy preserving sharing and data integration in mobile web environments " Journal of Chemical and Pharmaceutical Sciences(JCPS) Volume 9 Issue 2, April - June 2016.
[36] Sundarraj, B., Kaliyamurthie, K.P. Social network analysis for decisive the ultimate classification from the ensemble to boost accuracy rates 2016 International Journal of Pharmacy and Technology

[37] Sundarraj, B., Kaliyamurthie, K.P. A content-based spam filtering approach victimisation artificial neural networks 2016 International Journal of Pharmacy and Technology83.

[38] Sundarraj, B., Kaliyamurthie, K.P. Remote sensing imaging for satellite image segmentation 2016 International Journal of Pharmacy and Technology8 3 .

[39] Sivaraman, K., Senthil, M. Intuitive driver proxy control using artificial intelligence 2016 International Journal of Pharmacy and Technology84.

[40] Sivaraman, K., Kaliyamurthie, K.P. Cloud computing in mobile technology 2016 Journal of Chemical and Pharmaceutical Sciences92.

[41] Sivaraman, K., Khanna, V. Implementation of an extension for browser to detect vulnerable elements on web pages and avoid click jacking 2016 Journal of Chemical and Pharmaceutical Sciences92.

\section{AUTHORS PROFILE}

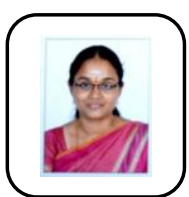

K.Shanmugapriya Assistant Professor, Department of Computer Science \& Engineering, Bharath Institute of Higher Education and Research, Chennai, India

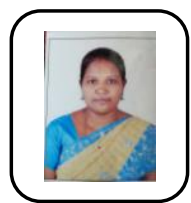

C.Geetha Assistant Professor, Department of Computer Science \& Engineering, Bharath Institute of Higher Education and Research, Chennai, India

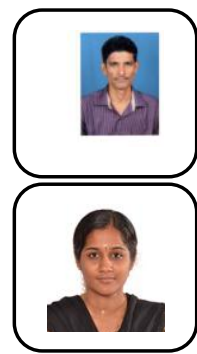

B.Sundaraj Assistant Professor, Department of Computer Science \& Engineering, Bharath Institute of Higher Education and Research, Chennai, India

S.R.Srividhya Assistant Professor, Department of Computer Science \& Engineering, Bharath Institute of Higher Education and Research, Chennai, India 